\title{
STUDIES ON STABILISED ADOBE BLOCKS
}

\author{
Bharath B ${ }^{1}$, Maheshwar Reddy L ${ }^{2}$, Juberahmed Pathan ${ }^{3}$, Rahul R Patel ${ }^{4}$ \\ ${ }^{I} U G$ Student, VIII SEM, Dept. of Civil Engineering, $R$ V C E, Bangalore, India \\ ${ }^{2} U G$ Student, VIII SEM, Dept. of Civil Engineering, $R$ V C E, Bangalore, India \\ ${ }^{3} U G$ Student, VIII SEM, Dept. of Civil Engineering, $R V C$ E, Bangalore, India \\ ${ }^{4} U G$ Student, VIII SEM, Dept. of Civil Engineering, $R V C$ E, Bangalore, India
}

\begin{abstract}
The construction practices of today demands production of alternative building materials which consume less energy and can be used for construction. One such material is the stabilized adobe bricks. In the present work, the adobes are prepared using the locally available soil in the nearby region in Bangalore. Since blocks purely made of soil are prone to shrinkage it is required to stabilize these blocks. Hence, an attempt is made to stabilize these blocks using lime and cement in varying proportions. The variation in properties like compressive strength, initial rate of absorption and water absorption are studied and compared..The main objective of this project is to analyze the various engineering properties of adobe bricks using lime as the stabilizer so as to establish the potential of these bricks as an alternative to traditional bricks. The present work aims at investigating lime as stabilizer to adobe brick mixes commonly used in Bangalore region. The results obtained ascertain that these can be used as a masonry unit in construction industries replacing other traditional materials which contain a lot of embodied energy.
\end{abstract}

Keywords: Alternative Building Material, Stabilized Adobe, Embodied Energy.

\section{INTRODUCTION}

Earth has been the most widely known and abundantly available material for human society to use it in construction. From the days of Egyptian and Mesopotamian earth is main part of any construction in its different forms. Local availability of mud makes its use advantageous, and ease of processing makes it one of the most energy efficient building material, cost effective and it is a very reliable material for any building in general and low cost buildings in particular. The technology of stabilized soil for wall construction has been known in India for more than 60 years.

Traditionally mud has been extensively used for building construction in India and elsewhere. Traditional earth construction technology has undergone a considerable change that enhances earth's durability and quality as a construction material for low-cost buildings. Such methods include rammed earth and machine compressed stabilized earth blocks. The construction practices of today heavily depend on materials like burnt bricks, cement, and other metals like steel, aluminum etc. These are energy intensive materials which consume a lot of energy and thus the production of these building blocks has a negative impact on environment. Since these materials can be produced only in particular areas there is a need to transport these materials to the site where they are to be used and again resulting in consumption of energy, so it is quite evident that these materials contain lot of embodied energy in them. Hence it is important to produce alternative building materials which consume less energy and can be used for construction.
One such material is the stabilized adobe bricks. Adobe in general means a stabilized sundried mud brick. It is sometimes useful to explore the potential of stabilized adobe. In this case, a stabilizing additive is added. Studies by various experts have shown the effectiveness in use of these blocks as construction materials. Adobe has been used in construction for thousands of years and even now about $30 \%$ of the population lives in earthen structures.

\subsection{Clay}

Clay is cohesive in nature. Under moist conditions, it imparts plasticity to the soil The presence of clay in moderate amounts in a soil is desirable. Since clay has cohesive nature, it imparts plasticity to the soil when under moist conditions. The existence of thin film of absorbed water which adheres strongly to the clay layers thus linking the particles together leads to plasticity. Thus, the clay minerals act as natural binding agents for the cohesionless granular fractions of a soil (gravel, sand, and silt).However the drawbacks associated with the clay is the fact that it has a high affinity towards water. Clayey soils swell in presence of water and shrinks in the absence of it. If the clay mineral is montmorillonite, this kind of swelling and shrinking is more prominent. Such volume instability is not highly undesirable in mortars. Therefore, soils which have clay content below $30 \%$ can be stabilized using cement and soils which clay content above $30 \%$ can be stabilized using lime 


\subsection{Lime}

Lime has the capacity to stabilize clayey soils through pozzolanic reaction. This reaction produces stable calcium silicate hydrates and calcium aluminate hydrates as the calcium from the lime reacts with the aluminates and silicates solubilized from the clay. It provides an economical way of soil stabilization. Lime modification describes an increase in strength brought by cation exchange capacity rather than cementing effect brought by pozzolanic reaction. In soil modification, as clay particles flocculates, transforms natural plate like clays particles into needle like interlocking metalline structures. Clay soils turn drier and less susceptible to water content changes. Lime stabilization may refer to pozzolanic reaction in which pozzolana materials reacts with lime in presence of water to produce cementitious compounds. The effect can be brought by either quicklime, $\mathrm{CaO}$ or hydrated lime, $\mathrm{Ca}(\mathrm{OH}) 2$. Slurry lime also can be used in dry soils conditions where water may be required to achieve effective compaction. Quicklime is the most commonly used lime; the followings are the advantages of quicklime over hydrated lime.

\subsection{Cement}

Cement is a binder, a substance that sets and hardens as the cement dries and also reacts with carbon dioxide in the air dependently, and can bind other materials together. Higher the grade of cement greater the strength achieved. It may be considered as primary stabilizing agent or hydraulic binder because it can be used alone to bring about the stabilizing action required. Cement reaction is not dependent on soil minerals, and the key role is its reaction with water that may be available in any soil. This can be the reason why cement is used to stabilize a wide range of soils. Numerous types of cement are available in the market; these are ordinary Portland cement, blast furnace cement, sulfate resistant cement and high alumina cement. Usually the choice of cement depends on type of soil to be treated and desired final strength. Hydration process is a process under which cement reaction takes place. The process starts when cement is mixed with water and other components for a desired application resulting into hardening phenomena. The hardening (setting) of cement will enclose soil as glue, but it will not change the structure of soil. The hydration reaction is slow proceeding from the surface of the cement grains and the centre of the grains may remain un-hydrated.

\section{EARLIER INVESTIGATIONS}

Following investigations have been made and established through various studies by the following:

Abhinandan G, JoswitaMelisha and Chethan N [1] in their studies on stabilized adobe blocks have tried to use varying percentages of cement as stabilizer and then have tested to ascertain the variation in properties of adobe blocks. According to their results they could obtain better quality of adobe at higher percentage of cement. This reference helped us in knowing the methodology of preparation of adobe blocks and also gave us the brief idea of what proportions of the constituent materials can be varied to get better strength.

Ashish Shukla, G.N. Tiwari, M.S. Sodha [2] in their Study on embodied energy of the adobe houses shows that approximately $370 \mathrm{GJ}$ energy can be saved per year. The energy payback time (EPBT) for the adobe house is 1.54 years.By using low energy intensive materials the mitigation of $\mathrm{CO}_{2}$ in the environment is reduced by an amount 101 tonnes/year. These results give the brief idea of the energy efficient nature of these blocks. These results also uphold the fact that adobe blocks are also environmental friendly.K.M.A. Hossain, L. Mol[3] have established that Volcanic ash/cement kin dust stabilized soils exhibit enhanced mechanical properties. Benefit of stabilization depends on type/dosage of stabilizer and combinations. Developed stabilized soils have potential to be used for construction applications. Uses of stabilized soils promote sustainable construction. These studies also specify the use of stabilisation of adobe blocks and their sustainability.

AgusSetyoMuntohar[4] in his thesis brought to the fore Utilization of lime and rice husk ash for soil stabilization produced considerable strength gain and other geotechnical properties of the stabilized soils. Its application could be also superior for construction materials as compressed-stabilized earth (CSE) or unfired-brick. The compactive energy required in compressed block and the energy in burnt brick are reduced in this adobe blocks but still the strength gain is comparable to those.

PinakinDhandhukia, DweipayanGoswami, ParthThakor, Janki N. Thakker [5] in their studies have explained that Physical parameter of soil like Atterberg's limits and soil grain size affects the compressive strength of the adobe blocks. Despite of the fact that any type of soil can be used in making adobe blocks, but from experiments it is known that that best results can be obtained for a particular composition of the soil. It is best to have clay content between $10-20 \%$ and sand greater than $50 \%$.

\section{EXPERIMENTAL PROCESS}

The present work focuses on characterizing the properties of stabilized adobe mud blocks. The characteristics like compressive strength, initial rate of absorption and water absorption are determined for different combinations of lime and cement. Various combinations of constituent materials adopted in making adobe blocks are given in table 1 . The proportions in this study are based on weight. 
Table -1: Material Compositions of adobe blocks

\begin{tabular}{|c|l|l|l|}
\hline $\begin{array}{c}\text { Block } \\
\text { Designation }\end{array}$ & \multicolumn{3}{|c|}{ Block Composition } \\
\hline- & SOIL & CEMENT & LIME \\
\hline B1 & $90 \%$ & $0 \%$ & $10 \%$ \\
\hline B2 & $88 \%$ & $0 \%$ & $12 \%$ \\
\hline B3 & $89 \%$ & $8 \%$ & $3 \%$ \\
\hline B4 & $85 \%$ & $5 \%$ & $10 \%$ \\
\hline
\end{tabular}

\subsection{Materials Used}

For the study, soil from a local site at BEML LAYOUT, Bangalore was used. Fundamental tests were conducted on the soil to ascertain both physical and engineering properties of soil. The basic properties of soil are tabulated in table 2 . Wet sieve analysis on the soil revealed $50 \%$ of soil particles were finer than 75 microns. Further, hydrometer analysis to determine the composition of fine grained soil particles in the specimen revealed $21 \%$ clay and $29 \%$ silt particles. The cement used is of OPC 53 grade, with initial setting time of 50 minutes and final setting time of 200 minutes. The lime bought in the form of powdered limestones, is slaked and used. In addition to this, effervescence test was conducted to check the quality of lime.

Table 2: Soil Properties

\begin{tabular}{|l|l|}
\hline PROPERTY OF SOIL & TEST RESULT \\
\hline Specific Gravity & 2.55 \\
\hline Liquid Limit & $37.5 \%$ \\
\hline Plastic Limit & $20 \%$ \\
\hline Shrinkage Limit & $14.25 \%$ \\
\hline Sieve analysis results & $\begin{array}{l}\text { Sand- } 50.17 \%, \text { Silt-28.96\%, } \\
\text { clay- } 20.87 \%\end{array}$ \\
\hline
\end{tabular}

The equipments required are $5 \mathrm{~mm}$ sieve, moulds, trowels and weighing balance. Required quantity of lime and soil will be weighed and the predetermined optimum water content will be added to the mixture. This mixture has to be pugged well manually for obtaining consistent mix. The optimum water content for making adobe can be determined by method of rolling a small quantity of soil into glossy ball between the hands and should not crumble when dropped from a height of about 0.5 meters. The mould has to smeared with oil in order to avoid soil sticking to the surface of the mould. The mix will then be filled in the precast mould of dimensions $230 \mathrm{~mm}$ X150mm X $100 \mathrm{~mm}$ and are to be compacted well by making smooth balls and by dropping them from a height of 0.5 meters (Image 1), so that the soil will compact in the mould without any voids, the corners and edges and to be given special attention and hence can be compacted by hands in order to avoid honeycombing.

The surface will be leveled using a trowel and then hand finishing will be done. De-moulding will be done on a level platform by tilting the mould upside down and ejecting the plate and lifting the mould slowly (Image 2).

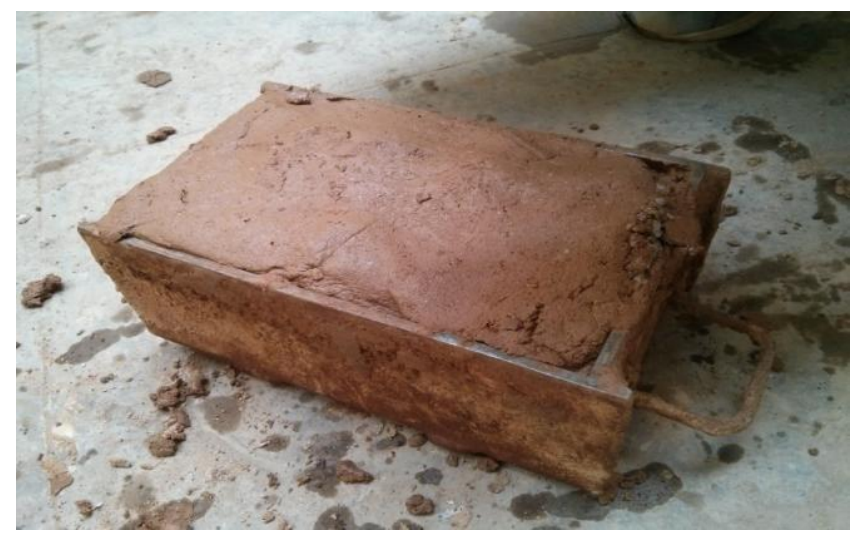

Image 1: Mould filled with pugged soil.

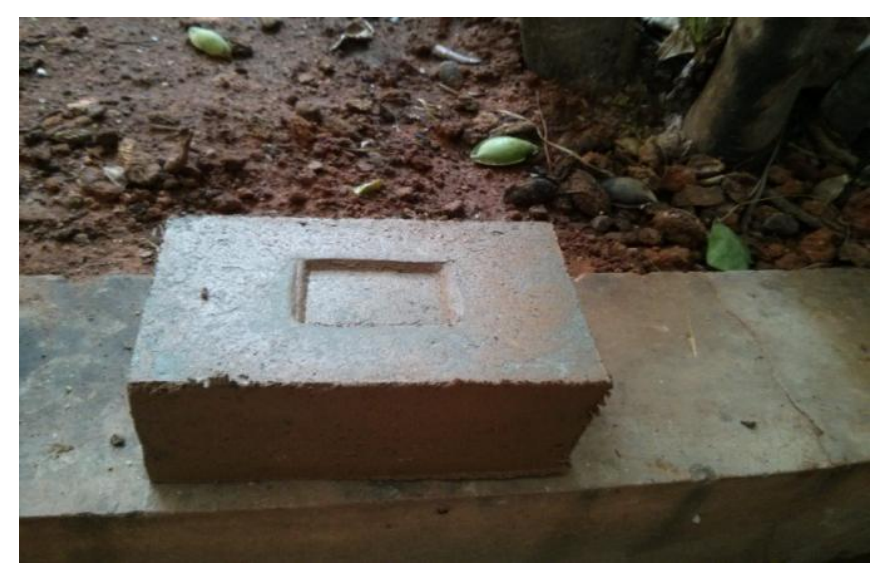

Image 2: De-moulded block

\section{TESTING PROCEDURE}

\subsection{Determination of Compressive Strength}

Blocks are air dried for 1 day and then stacked and moist cured for the following 28 days by covering them with gunny bags and keeping them moist. After 28 days, the blocks are dried and tested for dry compressive strength. The blocks are loaded under a compression testing machine, until the blocks fail under compression. For better consistency of results, 2 specimens per combination is tested. Similarly, blocks are also tested for wet compressive strength after immersing the blocks for 24 hours in water.

\subsection{Initial Rate of Absorption}

Initial rate of absorption is defined as the number of grams of water absorbed in one minute over an area of 30 square inches of brick bed area (ASTM C 67). Accordingly, the test specimen is placed in standard IRA test setup for a period of 1 hour and weighed. For better consistency, 2 blocks per 
specimen are tested simultaneously and results are obtained in grams/ min/ $30 \mathrm{sq}$ inch. The limiting value as per ASTM for IRA is $30 \mathrm{~g} / \mathrm{min} / 30 \mathrm{in}^{2}[6]$.

\subsection{Water Absorption}

Water absorption test is a test conducted over 24 hours to determine the quantity of water absorbed by a block. At first, cured specimens are air dried for a day and then it is submerged in water at a temperature of $27{ }^{\circ} \mathrm{C}$ for 24 hours (IS 3495)[7]. It is weighed again the following day and the quantity of water absorbed by the block is ascertained as a percentage of its initial mass.

\section{RESULTS AND DISCUSSIONS}

The compressive strength results were the most important results obtained from our project. The 28 days Strength was maximum for the combination containing more percentage of cement as expected attributed to its higher rate of hydration as compared to lime. Results can be observed from the table 5 . For the combinations containing lime the results of compressive strength at 28 days are less and are expected to be more at 90 days (Table 3 and Table 4).

Table -3: 10\% Lime (28 days results)

\begin{tabular}{|c|c|c|c|c|}
\hline $\begin{array}{c}\text { Spec- } \\
\text { imen }\end{array}$ & $\begin{array}{l}\text { Wet Comp* } \\
\text { Strength } \\
(\mathrm{MPa})\end{array}$ & $\begin{array}{c}\text { 28 days } \\
\text { Dry comp* } \\
\text { strength } \\
(\mathrm{MPa})\end{array}$ & $\begin{array}{c}\text { Initial } \\
\text { Rate of } \\
\text { Abs* } \\
(\text { IRA) } \\
(\mathrm{g} / \mathrm{min} / \\
\left.30 \mathrm{in}^{2}\right)\end{array}$ & $\begin{array}{c}\text { Water } \\
\text { Abs* } \%)\end{array}$ \\
\hline 1 & 1.44 & 2.42 & 0.840 & 18.23 \\
\hline 2 & 1.6 & 2.6 & 0.948 & 18.14 \\
\hline Avg* & 1.52 & 2.51 & 0.894 & 18.18 \\
\hline
\end{tabular}

Avg- Average, Comp- Compressive, Abs- Absorption

Table -4: 12\% Lime (28 days results)

\begin{tabular}{|c|c|c|c|c|}
\hline $\begin{array}{c}\text { Spec- } \\
\text { imen }\end{array}$ & $\begin{array}{l}\text { Wet Comp* } \\
\text { Strength } \\
(\mathrm{MPa})\end{array}$ & $\begin{array}{c}28 \text { days } \\
\text { Dry comp* } \\
\text { strength } \\
\text { (MPa) }\end{array}$ & $\begin{array}{c}\text { Initial } \\
\text { Rate of } \\
\text { Abs* } \\
(\text { IRA) } \\
(\mathrm{g} / \mathrm{min} / \\
\left.30 \mathrm{in}^{2}\right)\end{array}$ & $\begin{array}{c}\text { Water } \\
\text { Abs* (\%) }\end{array}$ \\
\hline 1 & 1.71 & 2.66 & 0.146 & 16.8 \\
\hline 2 & 1.92 & 2.76 & 0.299 & 16.76 \\
\hline Avg* & 1.815 & 2.71 & 0.223 & 16.78 \\
\hline
\end{tabular}

Avg- Average, Comp- Compressive, Abs- Absorption
Table -5: 3\% Lime and 8\% cement (28 days results)

\begin{tabular}{|c|c|c|c|c|}
\hline $\begin{array}{c}\text { Spec- } \\
\text { imen }\end{array}$ & $\begin{array}{l}\text { Wet Comp* } \\
\text { Strength } \\
(\mathrm{MPa})\end{array}$ & $\begin{array}{c}28 \text { days } \\
\text { Dry comp* } \\
\text { strength } \\
(\mathrm{MPa})\end{array}$ & $\begin{array}{c}\text { Initial } \\
\text { Rate of } \\
\text { Abs* } \\
(\mathrm{IRA}) \\
(\mathrm{g} / \mathrm{min} / \\
\left.30 \mathrm{in}^{2}\right)\end{array}$ & $\begin{array}{c}\text { Water } \\
\text { Abs* }(\%)\end{array}$ \\
\hline 1 & 4.67 & 6.085 & 0.339 & 12.23 \\
\hline 2 & 4.20 & 6.080 & 0.373 & 12.47 \\
\hline Avg* & 4.435 & 6.083 & 0.356 & 12.35 \\
\hline
\end{tabular}

Avg- Average, Comp- Compressive, Abs- Absorption

Table -6: $10 \%$ Lime and 5\% cement (28 days results)

\begin{tabular}{|c|c|c|c|c|}
\hline $\begin{array}{c}\text { Spec- } \\
\text { imen }\end{array}$ & $\begin{array}{l}\text { Wet Comp* } \\
\text { Strength } \\
(\mathrm{MPa})\end{array}$ & $\begin{array}{c}28 \text { days } \\
\text { Dry comp* } \\
\text { strength } \\
(\mathrm{MPa})\end{array}$ & $\begin{array}{c}\text { Initial } \\
\text { Rate of } \\
\text { Abs* } \\
\text { (IRA) } \\
(\mathrm{g} / \mathrm{min} / \\
\left.30 \mathrm{in}^{2}\right)\end{array}$ & $\begin{array}{c}\text { Water } \\
\text { Abs* }^{*} \%\end{array}$ \\
\hline 1 & 3.105 & 4.25 & 0.387 & 13.78 \\
\hline 2 & 3.140 & 4.24 & 0.426 & 13.19 \\
\hline Avg* & 3.123 & 4.245 & 0.407 & 13.49 \\
\hline
\end{tabular}

Avg- Average, Comp- Compressive, Abs- Absorption

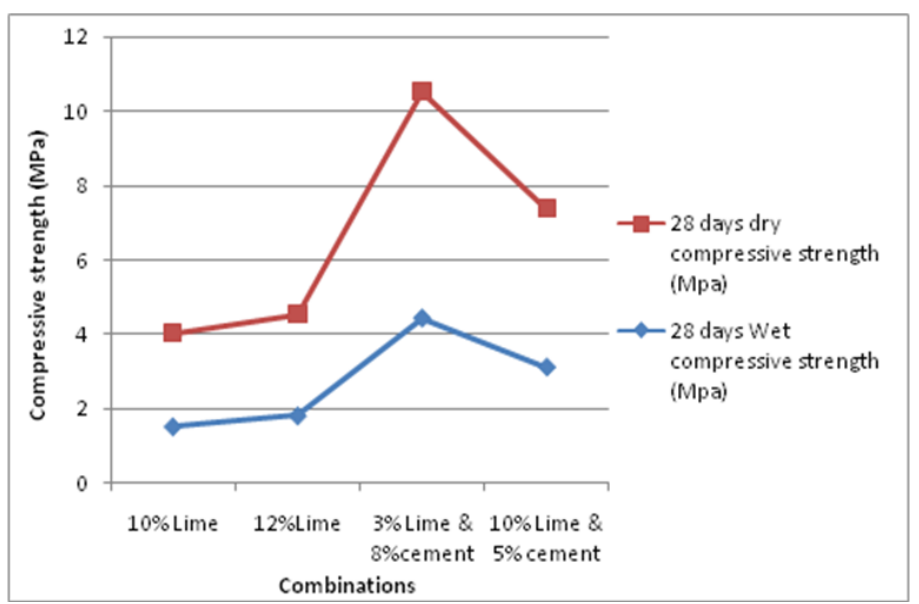

Chart 1: Compressive Strength Comparison

Dry compressive strength for all the combinations is higher as compared to wet compressive strength (Chart 1). 


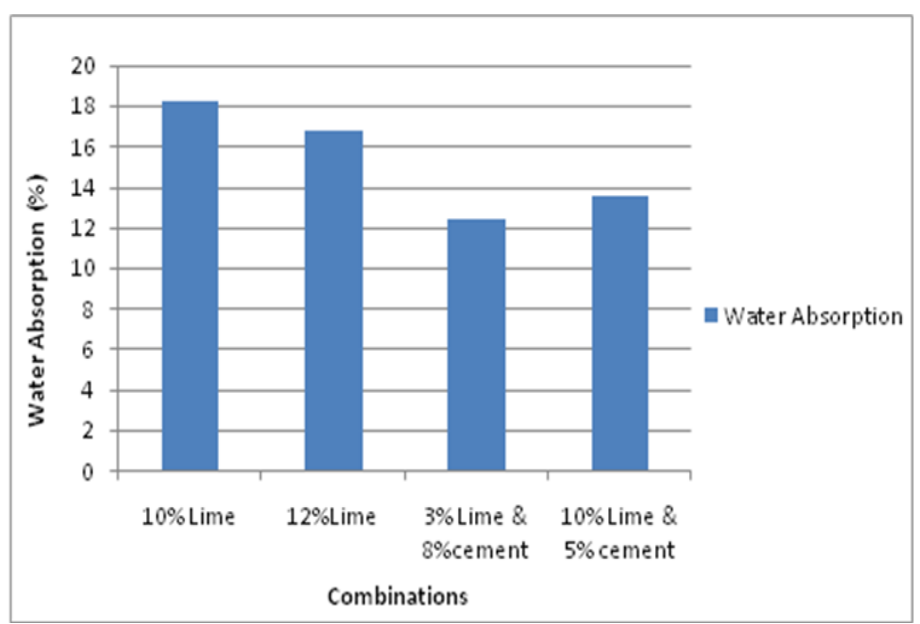

Chart 2: Water Absorption Comparison

Water Absorption is observed to be the least for combination containing more percentage of cement (Chart 2). This can be understood as the hydration products in these combinations are filling all the voids that may be present in the blocks.

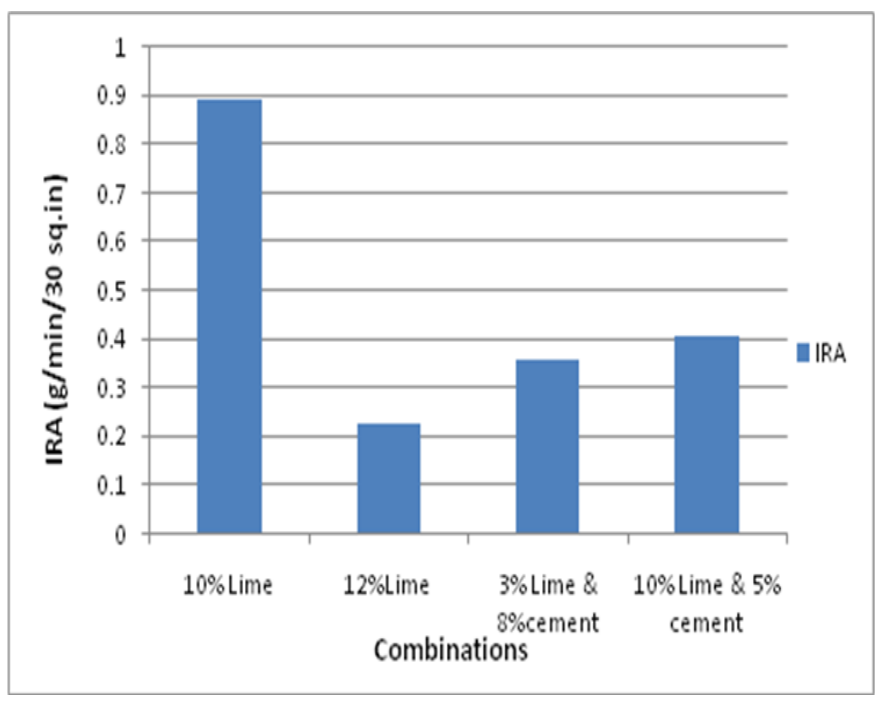

Chart 3: Initial Rate of Absorption Chart

Initial Rate of absorption is observed to be the less for higher lime combinations. Lime and cement combinations have shown consistent IRA results without much variations (Chart 3). This can be explained by the fact that cement being finer fills the voids effectively and resists the percolation of water.

\section{CONCLUSIONS}

$>$ The minimum compressive strength required for a building block to be used as a masonry unit as per IS 1905 is $3 \mathrm{Mpa}$. So the compressive strength obtained for adobe block is higher for all the combinations than this value and hence ascertain it to be used as a masonry unit.

$>$ Water absorption was also found to be well within the maximum limit of $20 \%$ allowed for masonry unit.

$>$ Initial rate of absorption of above blocks is found to have a maximum value of $0.9 \mathrm{~g} / \mathrm{min} / 30 \mathrm{in}^{2}$, which is acceptable as per ASTM C67.

$>$ The results obtained are all comparable to that of traditional Ist class bricks and IRA results of adobe blocks are better than those obtained for bricks, hence making it an potential alternative building blocks for burnt bricks.

$>$ The embodied energy in these blocks being almost negligibly less making them energy efficient building blocks. Also they are found to be cost effective.

\section{SCOPE FOR FURTHER STUDY}

The performance of these blocks under longer periods of curing can be ascertained, as lime is found to show higher strengths at longer days of curing. In addition to this, the performance of these blocks as a wall unit can be determined, by constructing prisms. Time and motion studies can be performed to ascertain the economics of casting of such blocks.

\section{ACKNOWLEDGEMENTS}

I wish to express my sincere thanks to Dr. K S JAGADISH, Professor, Dept. of Civil Engineering, RVCE, Bangalore for guiding us through all stages of the project.

I place on record, my sincere gratitude to Dr. B.C UDAYASHANKAR, Hod, Dept of Civil Engineering, RVCE, Bangalore for his constant encouragement extended to us.

I also thank Mrs S. NETHRAVATI, Assistant Professor, Dept of Civil Engineering, RVCE, Bangalore for her guidance and continuous support.

I would also like to thank all who, directly or indirectly have lent their support and ideas to our project.

\section{REFERENCES}

[1] Abhinandan G, JoswitaMelisha and Chethan $\mathrm{N}$, "Studies on stabilized adobe block for low energy masonry buildings", the final year project in The National Institute Of Engineering (NIE), Mysore in the year 2013. This was KSCST sponsored project under $36^{\text {th }}$ series of SPP.

[2] Ashish Shukla, G.N. Tiwari, M.S. Sodha, "Embodied energy analysis of adobe house", journal on Renewable Energy, Volume 34, Issue 3, March 2009, pp 755-761.

[3] K.M.A. Hossain, L. Mol, "Some engineering properties of stabilized clayey soils incorporating natural pozzolans and industrial wastes", journal on 
Construction and Building Materials, Volume 25, Issue 8, August 2011, pp 3495-3501.

[4] AgusSetyoMuntohar, "Engineering characteristics of the compressed-stabilized earth brick", journal on Construction and Building Materials, Volume 25, Issue 11, November 2011, pp 4215-4220.

[5] PinakinDhandhukia, DweipayanGoswami, ParthThakor, Janki N. Thakker, "Soil property apotheosis to corral the finest compressive strength of unbaked adobe bricks", journal on Construction and Building Materials, Volume 48, November 2013, Pages 948-950.

[6] ASTM C 67 (13a) Standard test methods for sampling and testing brick and structural clay tile.

[7] IS-3495(Part 1-4:1992) Indian Standard methods of burnt clay building bricks.

\section{BIOGRAPHIES}

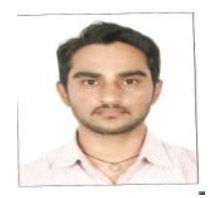

BHARATH B is a final year student of Civil Engineering at RVCE, Bangalore. His area of interest includes Green Building Technology.

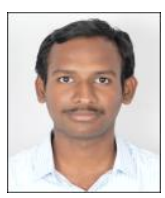

MAHESHWAR REDDY $L$ is a final year student of Civil Engineering at RVCE, Bangalore. His area of interest includes Energy Efficient construction methods.

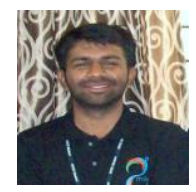

JUBERAHMED PATHAN is a final year student of Civil Engineering at RVCE, Bangalore. His area of interests includes Low Cost Housing.

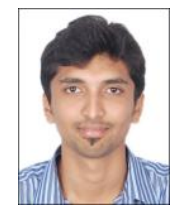

RAHUL R PATEL is a final year student of Civil Engineering at RVCE, Bangalore. His area of interests includes Alternative Building Materials and Technology. 